\title{
Susceptibility to DNA damage in workers occupationally exposed to pesticides, to tannery chemicals and to coal dust during mining
}

Katia Kvitko ${ }^{1}$, Eliane Bandinelli ${ }^{1}$, João A.P. Henriques ${ }^{1}$, Vanina D. Heuser ${ }^{1}$, Paula Rohr ${ }^{1}$, Fernanda R. da Silva ${ }^{1}$, Naye Balzan Schneider ${ }^{1,2}$, Simone Fernandes ${ }^{1}$, Camile Ancines ${ }^{1}$ and Juliana da Silva ${ }^{2}$

${ }^{1}$ Departamento de Genética, Universidade Federal do Rio Grande do Sul, Porto Alegre, RS, Brazil.

${ }^{2}$ Laboratório de Genética Toxicológica, programa de Pós-graduação em Genética Toxicológica, Universidade Luterana do Brasil, Canoas, RS, Brazil.

\begin{abstract}
Our mutagenesis group has been studying with important economic drivers of our state, such as agriculture, the footwear and leather industry and open-cast coal mining. Working conditions in these sectors have potentially harmful to humans. The aim of these studies is to determine the health risk of workers by biomonitoring subjects exposed to genotoxic agents. The main results of our studies with vineyard farmers we observed a high rate of MN and DNA damage in individuals exposed to pesticides $(p<0.001)$. In addition, some effects of genetic polymorphisms in the modulation of MN results were observed in this group. Tobacco farmers were also evaluated at different crop times. The results showed a significant increase in the Damage index and frequency in tobacco farmers compared to the non-exposed group, for all crop times. The results for footwear and tannery workers showed a significant increase in the mean ID for the solvent-based adhesive $(p<0.001)$ group in comparison to the water-based adhesive group and control $(p<0.05)$. For open-cast coal mine workers, the EBCyt indicated a significant increase in nuclear bud frequency and cytokinetic defects in the exposed group compared to the non-exposed group $(p<0.0001)$. We were able to associate specific genetic susceptibility with each type of exposure and with the non-use or improper use of personal protection equipment and diet adequacy. These results show how important the continuous education of exposed workers is to minimizing the effect of the occupational exposure and the risk of disease associated with the work.
\end{abstract}

Keywords: occupational exposure, Comet assay, micronucleus test, pesticide, coal dust.

\section{Occupational Hazard and Biomarkers}

Biomonitoring of human populations exposed to potential mutagens or carcinogens can serve as an early detection system for the initiation of cell deregulation in the development of cancer. Environmental disease is seen as the result of exposure to environmental stressors (including nutrition) modulated by individual susceptibility factors. Molecular epidemiological approaches using molecular markers have been in use for almost two decades in the fields of environmental medicine, human biology, pathology and especially in monitoring environmental and occupational exposure (Angerer et al., 2007; Dusinska and Collins, 2008).

Exposure to genotoxic agents can be associated with human reproductive problems. Couples with fertility problems exhibit higher frequencies of MN than fertile couples;

Send correspondence to Kátia Kvitko. Departamento de Genética, Universidade Federal do Rio Grande do Sul, Caixa Postal 15053, 91501-970 Porto Alegre, RS, Brazil. E-mail: katia.kvitko@ ufrgs.br.
MN in peripheral blood lymphocytes in males correlates positively with DNA damage in sperm; an abnormally high frequency of $\mathrm{MN}$ in peripheral blood lymphocytes is associated with pregnancy complications including miscarriage, intra-uterine growth restriction and pre-eclampsia. The studies published to date consistently indicate an association of $\mathrm{MN}$ in peripheral blood lymphocytes with impaired reproductive capacity. (Fenech, 2011; Keshava and Ong, 1999; Weselak et al., 2008).

The relevance of an increased frequency of cytogenetic alterations as cancer risk biomarkers is further supported by epidemiological studies suggesting that a high frequency of DNA damage is predictive of an increased risk of cancer (Bonassi et al., 2005).

As cancer incidence and mortality have limited usefulness for the prevention of disease, they are detectable only after the onset of cancer development or death, studies using intermediate markers in healthy workers are important in assessing the risk of carcinogenicity. More efforts are needed to detect and identify substances of occupa- 
tional hazard, as well as to establish appropriate diseaserelated biomarkers either at chemical, physiological, cellular and sub-cellular, or molecular levels, to facilitate the prevention of occupation-induced cancers (Keshava and Ong, 1999; Ward et al., 2003).

The biomonitoring of exposure to chemical agents requires measurement of the substance or their metabolites in different body fluids, such as blood, urine and exhaled air. The concept of biological monitoring also includes the early detection of adverse and non-reversible effects (Dougherty, 1998; United Nations Environment Programme, 2001; Angerer et al., 2007). The term "biomarker" is used to express a specific measure of interaction between a given biological system and a genotoxic agent (United Nations Environment Programme. et al., 2001; Bonassi and Au, 2002; Cebulska-Wasilewska, 2003; Angerer et al., 2007). Biomarkers of exposure as tools for assessing occupational exposure are also used in epidemiological studies, seeking to establish a relationship between exposure to a chemical agent and a health effect on exposed individuals. The importance of using these biomarkers as biological parameters of exposure to chemicals lies in the fact that they are more directly related to the health effect than environmental parameters and can thus offer better risk estimates (Angerer et al., 2007).

A wide range of methods is presently used for the detection of early biological effects of DNA-damaging agents in occupational settings. The frequency of chromosomal aberrations (Sturgis et al., 1999) in peripheral blood lymphocytes has for many years been applied as a biomarker of early effects of genotoxic agents in occupational and environmental settings (Bonassi et al., 2005). During the last few years, a need for methods that are less time-consuming has arisen, as it is in the public interest that hazardous chemicals are removed from the environment as soon as possible. Consequently, there is a need for rapid and reliable tests that detect DNA damage caused by agents under different exposure circumstances. Thus, the Micronucleus test $(\mathrm{MN})$ and the Comet assay seem to satisfy many of these criteria, which are used in human biomonitoring studies (Fairbairn et al., 1995; Moller et al., 2000; Grover et al., 2003; Bonassi et al; 2011).

Some parameters of genotoxicity have influenced their results due to non-occupational factors. Therefore, in order to increase the relevance of these tests it is important to assess which factors contribute significantly to the variation found among the subjects studied. Factors such as genetic predisposition, age, sex, diet and lifestyle may influence the susceptibility of occupationally exposed individuals as well as increasing the baseline rate of cytogenetic change in a reference population.

DNA polymorphisms are another group of genetic susceptibility factors that could influence the level of DNA damage by affecting the individual's metabolism and repair of various DNA lesions induced by genotoxic exposure. The genes examined by us included polymorphisms in xenobiotic metabolyzing /detoxification Phase I or II and some repair genes.

Our research group has been working with occupational exposure with special focus on several important industries in the State of Rio Grande do Sul, Brazil. Our main goal was to demonstrate whether each sector presents a health risk related to the occupational activity and develop an educational program to show the importance of the correct use of personal protection equipment.

\section{Exposure to Pesticides}

Pesticides are used extensively all over the world and in recent years their use has risen. Large amounts of these chemicals are released into the environment, and many of them affect non-target organisms, posing a potential hazard to human health. Pesticide exposure is ubiquitous, not only from agricultural pesticide use and contamination of foods, but also from the extensive use of these products in and around households. Individuals occupationally exposed to pesticides (such as field workers, mixers, loaders, appliers, etc.), who are in direct contact with these chemicals, may provide a good opportunity to study these adverse health consequences.

Exposure to pesticides has been associated with an increase in the incidence of non-Hodgkin's lymphoma (Hardell and Eriksson, 1999; Zheng et al., 2001), multiple myeloma (Khuder and Mutgi, 1997), soft tissue sarcoma (Kogevinas et al., 1995), lung sarcoma (Blair et al., 1983), pancreatic, stomach, liver, bladder and gall bladder cancer (Ji et al., 2001; Shukla and Arora, 2001), Parkison's disease (Gauthier et al., 2001) and reproductive outcomes (Arbuckle et al., 2001), among others.

Regarding pesticide exposure, many reports dealing with chromosomal aberrations (Au et al., 1999; Zeljezic and Garaj-Vrhovac, 2001), sister chromatid exchange (Shaham et al., 2001; Zeljezic and Garaj-Vrhovac, 2002), micronuclei (Falck et al., 1999; Pastor et al., 2003) and Comet cells (Zeljezic and Garaj-Vrhovac, 2001; Grover et al., 2003) found significant increases in these biomarkers, providing suggestive evidence of genotoxic effects induced by pesticides.

In view of these findings, the detection of populations at risk constitutes a very important topic. Thus, the Micronucleus test (MN) and the Comet assay seem to satisfy many of these criteria, which are used in human biomonitoring studies (Fairbairn et al., 1995; Moller et al., 2000; Grover et al., 2003).

In order to assess whether prolonged exposure to complex mixtures of pesticides could lead to an increase in cytogenetic damage, vineyard workers and tobacco farmers 
and workers exposed to pesticides were evaluated using the Micronucleus test and Comet assay in peripheral leukocytes. In order to evaluate whether genetically determined individual variations in xenobiotic metabolizing capacity could modify individual susceptibility to the possible genotoxic effects of pesticides, the subjects were genotyped for several genes.

The study on vineyard workers involved a total number of 173 individuals: 108 were agricultural workers exposed to pesticides and 65 were controls (da Silva et al., 2008). This study showed a high rate of MN and DNA damage in pesticide-exposed individuals $(\mathrm{p}<0.001$; MannWhitney $U$ test). In addition, some effects of genetic polymorphisms in $P O N$ in the modulation of MN results were observed in the exposed group, and an association between GSTM1, GSTT1 and CYP2E1 polymorphisms was suggested. In addition, some effects of genetic polymorphisms in $P O N$ in the modulation of $\mathrm{MN}$ in the exposed group were observed, and an association between GSTM1, GSTT1 and CYP2E1 polymorphisms was suggested.

Considering the importance of repair mechanisms, OGG1 and XRCC1 are examples of important proteins of the BER pathway (Goode et al., 2002; Au et al., 2004; Hao et al., 2004; Muniz et al., 2008). In another study we evaluated whether the two BER polymorphisms (OGG1 Ser326Cys: rs1052133; and XRCC1 Arg194Trp: rs 1799782) or the combined genotypes of these polymorphisms with PON1 Gln192Arg modify individual genotoxic susceptibility to pesticide exposure in vineyard workers, as measured by micronucleus formation and DNA damage induction in peripheral leukocytes. Our study showed that the polymorphisms in the BER pathway could modulate susceptibility to DNA damage caused by pesticide exposure (Rohr et al., 2011). Significant increases in DI and DF were observed in Cys/- (Cys/Cys or Cys/Ser)-exposed individuals in relation to $O G G I \mathrm{Ser} / \mathrm{Ser}$ individuals (DI: $p=0.032$ and DF: $p=0.009$ ). The XRCC1194 polymorphism has no effect on the studied biomarkers. Considering the combined influence of the PON1 gene and the $O G G 1$ gene, encoding metabolism and DNA repair functions respectively, we observed higher DNA damage in the exposed group of individuals with a less efficient $C y s$ allele, regardless of $P O N 1$ genotype and significant results in $\mathrm{MN}$ formation when combined with XRCC1194 and PON1 genotype analyses in the exposed group. As this repair pathway is the major cellular defense against oxidative DNA damage, our results support the existing evidence that suggests the involvement of oxidative damage in the pesticide-induced genotoxic effects. Thus, our study reinforces the importance of considering the combined effect of metabolizing and repair variant genotypes on the individual susceptibility to incorporate DNA damage, as these two processes act coordinately in determining the final response to pesticide exposure (Rohr et al., 2011).

Located in southern Brazil, the municipality of Santa Cruz do Sul (Rio Grandedo Sul) is an important producer of tobacco leaves (Nicotiana tabacum). With an annual production of over 687,180 tons, the activity provides employment to over 223,000 farmers (AFUBRA, 2011). Health risks associated with smoking tobacco and exposure to secondhand smoke are well known. The effects of handling wet tobacco leaves, however are only poorly studied. Green Tobacco Sickness (GTS) is a form of nicotine poisoning that affects workers that have direct contact with tobacco plants during cultivation and harvesting (Mc Bride et al., 1998). Although GTS has not been associated with mortality or long-term morbidity, it causes significant discomfort and productivity loss among tobacco workers. People involved in preparing and spraying pesticide mixes are the most commonly exposed group of farmers (Bolognesi, 2003). Many of these compounds are classified as carcinogenic by the International Agency for Research on Cancer (IARC). In this scenario, the evaluation of the effects of occupational exposure to these products becomes an important field of study. In Brazil, tobacco farmers usually apply several pesticides (insecticides, herbicides, fungicides and plant growth regulators) onto tobacco plants to improve crop characteristics and yield.

The objective of our other study with tobacco farmers was to determine the genotoxic effects in a group of workers occupationally exposed to agrochemicals and nicotine. Peripheral blood samples were collected from 30 agricultural workers ( $42.10 \pm 10.15$ years), in different crop times (off-season [I], during pesticide application [II] and leaf harvest [III]), and 30 who were not exposed (42.10 \pm 10.15 years). As a biomarker of occupational exposure, we obtained data on DNA damage detected by the Comet assay. The results showed significant increase in the Damage in$\operatorname{dex}(\mathrm{I}: 14.53 \pm 13.98$; II: $15.24 \pm 12.78$; III: $17.59 \pm 10.23$ ) and frequency (I: $10.57 \pm 7.83$; II: $8.76 \pm 6.15$; III: $13.59 \pm$ 10.23) in tobacco farmers compared to the non-exposed group (DI: $1.55 \pm 1.36$; DF: $1.34 \pm 7.63$ ), for all crop times. No correlation was found between age, PPE use and exposure time in relation to DNA damage observed in the Comet assay. A difference, although not significant, was found between gender and exposure. DNA damage was higher in males than females, though not statistically significant ( $p>0.05$; ANOVA). Moreover, females presented increased DNA damage during leaf harvest compared to off-season and pesticide application phases $(\mathrm{p}>0.05)$. This investigation suggests DNA damage rises in all tobacco crop stages, though more so during the tobacco leaf harvest phase. More worker protection regulations should be enacted to prevent the health problems of tobacco farmers. 
Our study with tobacco farmers demonstrates the presence of genotoxic effects in blood cells and exfoliated buccal cells of agricultural workers exposed to pesticides $(\mathrm{p}<0.001)$. These findings appeared during the high exposure period, when pesticides are more frequently applied, at times daily. During the low exposure period, when the pesticides are almost never used, the values detected in the Comet assay, the Micronucleus test and Superoxide dismutase assay were lower than those observed during the high exposure period, and the values were restored to low levels. However, it is important to emphasize that protective measures are essential to avoid potential risks to human health. In addition, some effects of genetic polymorphisms in the PON1 gene in the modulation of micronucleus results were observed in the exposed group, where the exposed homozygote $G \ln / G \ln$ individuals showed higher genotoxic effect of these pesticides, as they presented the highest MN frequency. Our findings indicate that agricultural workers have higher levels of DNA damage in somatic cells, suggesting a potential health risk for these workers. Risk assessment of pesticide users is crucial to prevent long-term health hazards from developing into cancer and other degenerative diseases.

Various micronutrients of the diet play an important role in genomic stability. Nutrient imbalances, deficiencies and excessive exposure to environmental mutagens and carcinogens can enhance genetic damage. Deficiency of folate and other vitamin $\mathrm{B}$ cofactors $\left(\mathrm{B}_{12}\right.$ and $\left.\mathrm{B}_{6}\right)$ also may cause defective DNA repair. The MTHFR C677T allele presents reduced activity, and therefore promotes functional folate deficiency. Therefore, the aim of this study was to evaluate influences of the intake of the micronutrients $\mathrm{B}_{12}, \mathrm{~B}_{6}$ and folate and the MTHFR C677T polymorphism on DNA damage in pesticide exposed individuals. We conducted a study that involved 113 individuals: 56 (mean age: $42.89 \pm 15.79$ years) farmers from Venâncio Aires (State of Rio Grande do Sul, Brazil) and 57 nonexposed individuals (mean age: $43.12 \pm 14.83$ years). They were sampled during tobacco harvest (July to December of 2008/2009) and pesticide application. Blood was collected and submitted to Comet assay, DNA extraction and PCRRFLP. The nutritional status was evaluated on the basis of the mean results of three recordatory 24-hour inquest (RI). The data were computerized, and the intake of nutrients and micronutrients was estimated using the Food Process program. Our analysis showed comet assay values with a significant increase in damage index (DI) and damage frequency (DF) $(\mathrm{p}<0.001)$ for the exposed group as compared to the control group (Mann-Whitney U-test). In our study the individuals with deficiency of folate and B12 vitamin presented a significant increase in the formation of $\mathrm{MN}$ in lymphocytes, supporting the hypothesis that folate adequacy and B12 vitamin may be protective against the mutagenic action of pesticides. Dietary adequacy, for both folate and B12 could be assisting in adequate repair. The analyses of genetic susceptibility didn't demonstrate significant association of MTHFR C677T polymorphism with DI and DF. In conclusion, our results indicate that the tobacco farmers studied have experienced genotoxic exposure, which is manifest as an increase in repairable DNA damage detected by Comet assay, maybe due to heavy and repeated use of pesticides. This effect was influenced by consumption of folate and B12 as this association is described in literature. In the current post-genomic era, different opportunities and challenges have emerged in the context of nutritional research, therefore nutrigenomics plays a huge role in elucidating the complex relation between nutrition and health and establishing the best individual dietary recommendations.

\section{Workers in Footwear and Tannery Industry}

Several investigations report increased mortality from cancer in tannery and footwear workers, as well as increases in the frequency of cytogenetic biomarkers. As these industries are some of the most important ones in southern Brazil, we decided to examine whether occupational exposure in these occupational settings could pose genotoxic risk to workers. Footwear workers are routinely exposed to complex mixtures of solvents in degreasers, cleaners, primers and adhesives used in the production process that contain toluene, $n$-hexane, acetone and possibly dust particles, additives in shoe materials and degradation products of materials. None of these solvents are considered genotoxic or carcinogenic on their own (Flowers et al., 2003; Life Systems Inc. et al., 1994, 1999a,b, 2000, 2010; United States Environmental Protection Agency, 2003). However, the health effects of organic mixtures are not well known, and the elevated risk is considered to be a consequence of the exposure to this complex mixture (Uuksulainen et al., 2002).

The recognition of the potential health hazards of solvent-based adhesives (SBAs) has led to the development of adhesives with no organic solvents, water-based adhesives (WBA). We investigated footwear workers (all males) exposed to SBA $(n=29)$ (for about 4 years), and WBA $(n=16)$, who had spent the six months previous to the study employed in an experimental section which used only water-based adhesives, although they had previously worked in sections which used solvent-based adhesives (for about 5 years). The control group was composed of 25 healthy subjects (Heuser et al., 2005). The Comet assay and the micronucleus test were used as endpoints, while traditional parameters for assessing exposure to toluene in organic mixtures by measuring the concentration of urinary hippuric acid were also assessed. Our results showed a significantly lower mean concentration of hippuric acid in the 
control group than found in the SBA $(\mathrm{p}<0.001)$ and WBA $(p<0.05)$ groups. The Comet assay results showed that there was a significant increase in the mean damage index for the SBA group $(p<0.001)$ in comparison to the WBA and control groups $(p<0.05)$. For the micronucleus test in binucleated lymphocytes and exfoliated buccal cells the three groups were not statistically different. The inference is that water-based adhesives are clearly a better option for safeguarding the health of footwear workers, even with the possible presence of isocyanate, while the positive results observed in the SBA group might be explained by the presence of chloroprene in the adhesive.

The second objective was to determine the genotoxic effects in a group of footwear workers occupationally exposed to solvent-based adhesive and solutions containing organic solvents, mainly toluene, in relation to susceptibility genes (Heuser et al., 2007). Peripheral blood and buccal cell samples were collected from 39 footwear workers (31 males and 8 females) and 55 controls (44 males and $11 \mathrm{fe}-$ males). As a biomarker of exposure, we obtained data on hippuric acid (HA), the main metabolite of toluene in urine, and DNA damage detected by the Comet assay in blood cells. Micronucleus frequencies in binucleated lymphocytes (BNMN) and in epithelial buccal cells (EBCMN) were analyzed as biomarkers of effect, while polymorphisms in the genes GSTT1, GSTM1, GSTP1, CYP1A1 and CYP2E1 were used as susceptibility biomarkers. Results of HA and Comet assay showed statistically increased values amongst footwear workers relative to controls $(\mathrm{p} \leq 0.001)$. No differences were observed in BNMN and EBCMN frequencies between the groups, but a correlation test revealed that age was significantly associated with BNMN frequency in both control $(r \mathrm{~s}=0.290 ; \mathrm{p} \leq 0.05)$ and exposed groups $(r \mathrm{~s}=0.674 ; \mathrm{p} \leq 0.001)$. Regarding the results on genetic polymorphisms, GSTM1 null subjects from the control group showed a significant increase in EBCMN frequency relative to GSTM1 non-null subjects $\mathrm{p} \leq 0.05$ ). A significant increase in DNA damage detected by the Comet assay in leukocytes was denoted for GSTP1 Ile/Val or $\mathrm{Val} / \mathrm{Val}$ individuals from the exposed group relative to those with GSTP1 Ile/Ile ( $\mathrm{p} \leq 0.05)$, especially in younger subjects $(\mathrm{p} \leq 0.01)$, and a nonsignificant trend for interaction with CYP2E1 polymorphism was found. This was confirmed by, stepwise multiple regression analyses between the different independent variables, showing that about $25 \%$ of the levels of DNA damage in footwear worker can be associated with genetic polymorphisms in GSTP1 and CYP2E1 ( $\mathrm{p}=0.006, F=5.876)$.

Brazil is one of the largest producers of bovine leather in the world, with the main concentration of producers located in the states Rio Grande do Sul and São Paulo. With more than 700 companies, tanneries directly employ about 65,000 workers.
Workers employed in leather tanning companies may be exposed to higher-than-normal levels of chromium, mostly trivalent chromium (Cr(III)) (Life Systems Inc et al., 2008), either in the form of inorganic $\mathrm{Cr}(\mathrm{III})$ compounds or as Cr bound to protein (leather dust) (Stupar et al., 1999). Toxicity for $\mathrm{Cr}(\mathrm{III})$ is very low, even when present in very large quantities, while hexavalent chromium $(\mathrm{Cr}(\mathrm{VI}))$ has been found to be biologically active. The failure of $\mathrm{Cr}(\mathrm{III})$ ions to pass the cell membrane explains the genetic inertness of $\mathrm{Cr}(\mathrm{III})$. Nonetheless, some data suggest that in mammalian cells endocytosis allows $\mathrm{Cr}$ (III) complexes to pass through the membrane barrier and enter cells. $\mathrm{Cr}$ (III) compounds are 1000-times less toxic than $\mathrm{Cr}(\mathrm{VI})$ compounds (Life Systems Inc et al., 2008), but may cause toxicity at higher concentrations and/or depending on its ligand (Bagchi et al., 2002).

Relatively few studies are available in the literature that directly address the toxicity of $\mathrm{Cr}$ (III), particularly exposure through inhalation. This lack of data results in considerable uncertainty regarding the hazard associated with exposure to $\mathrm{Cr}$ (III) (Grevatt and United States. Environmental Protection Agency, 1998; Medeiros et al., 2003). Concentrations of chromium in blood, serum, urine and hair have long been used in biological monitoring of environmentally and occupationally exposed populations, as a biomarker of exposure (Simpson and Gibson, 1992; Rajaram et al., 1995; Grevatt and United States. Environmental Protection Agency, 1998; Stupar et al., 1999; Medeiros et al., 2003).

Genotoxicity evaluations were also carried out in a group of 45 male leather workers, regardless of the section in the tannery (Heuser et al., unpublished) in comparison to 40 healthy male subjects as controls. As observed in the first study, most biomarkers of exposure (chromium in urine, methemoglobin, and reparable DNA damage measured by Comet assay) failed to show marked differences between the group, with exception of lower hemoglobin levels in tannery workers. However, although no difference was found between controls and tannery workers regarding EBCMN frequencies, the other biomarkers of early effect used, BNLMN and NPB, were significantly increased in tannery workers ( $\mathrm{p}<0.05$ and $\mathrm{p}<0.0001$, respectively). Individual variation in the genes GSTT1, GSTM1, GSTP1, CYP1A1 and CYP2E1 used as biomarkers of susceptibility suggested modulation of the genotoxicity by enzymes of the CYP450 system, since tannery workers with the CYP2E $1 * 1 A{ }^{*} 1 A$ (the wild type) had increased values in DNA damage measured by Comet assay in comparison to CYP2E1 variant genotypes $(* 1 A / * 5 B$ or $* 5 B / * 5 B)$ $(\mathrm{p}<0.03)$. The different GST genotypes investigated did not influence the level of cytogenetic damage between groups. 
Although it may not be possible to point out a single genotoxic agent in the workplace, our data indicate the presence of genotoxic exposure in the tannery and footwear industry, with increased values in older subjects, opening a discussion about the possibility of higher accumulated damage in exposed people, since a positive correlation was found between age and BNLMN frequency in all the study groups.

\section{Open-Cast Coal Miners}

Coal is a mixture of a variety of chemicals, especially hydrocarbons, which may give rise to polycyclic aromatic hydrocarbons (PAH). Many PAH compounds produce mutagenic and carcinogenic effects. Potentially, all technological processes associated with open fire or temperatures between $400-600{ }^{\circ} \mathrm{C}$, which may lead to $\mathrm{PAH}$, should be considered potentially hazardous (Sram et al., 1985). Mineral coal in Rio Grande do Sul (RS), the southernmost state of Brazil, exceeds 30 X 109 tons, i.e., about $87 \%$ of the Brazilian reserves. The coal of this state, typically obtained through stripping operations, is of low quality and generally contains $1 \%$ to $5 \%$ sulfur. It is primarily used in a power plant located in the municipality of Candiota in Rio Grande do Sul. This region produces 38\% of the country's coal. Consequently, a broad range of coal and derivatives (metals, hydrocarbons, etc.) is added to the chemical load of the atmosphere and water in the region. It is also well documented that coal-fired power plants discharge a higher amount of radioactive material into the atmosphere than nuclear plants of comparable size.

The potential environmental risk that PAHs and their derivatives represent is currently the focus of study for the entire scientific community. Great efforts have been made in the search for experimental procedures to study the reactivity of the mechanism of transformation, quantify such compounds and set research priorities for the study of PAHs. Due to their characteristics, 16 hydrocarbons are listed as organic priority pollutants by the U.S. Environmental Protection Agency (EPA). Some of these types of PAHs are found in extracts of the coal mines Leão (RS) and Candiota (RS), such as phenanthrene, anthracene, fluoranthene, pyrene, benzo (a) anthracene, chrysene, triphenylene, benzo (e) pyrene, indeno (1,2,3-cd) pyrene, benzo (a) pyrene and benzo $(\mathrm{g}, \mathrm{h}, \mathrm{i})$ perylene.

The importance of coal as an energy source makes its characterization and estimation of risks of extreme importance to the safety of those individuals and the environment. In studies conducted with different organisms in coal mining areas and coal and its derivatives have shown increased DNA damage. Silva et al. (2000) observed an increase in the number of micronuclei (MN) and levels of damage detected in the Comet Assay torquatus Ctenomys (tuco-tuco) mining regions of the state of Rio Grande do
Sul compared to areas without coal. Annelids (Lumbricus spp.) have been used to test for DNA damage from exposure to coke (Verschaeve and Gilles, 1995). Many others have demonstrated the harmful effect of coal and its derivatives in various cell lines (Leonard et al., 1984; Granella and Clonfero, 1992; Gu et al., 1992; Stierum et al., 1993). A study of workers in open coal mines, as well as those working in excavations, revealed an increase in the rate of chromosomal aberrations, sister chromatid exchange and MN (Leon-Mejia et al.; Sram et al., 1985; Donbak et al., 2005). An induction of chromosomal aberrations, sister chromatid exchange in workers and a high frequency of MN were also observed in power plants that use coal as an energy source (Sram et al., 1985; Siwinska et al., 2004;).

The metabolizing and repair systems are important exposure effect modulators. The aim of our study was to evaluate DNA damage in coal miners from Candiota using the Comet assay and the genetic modulation by metabolizing and repair genotypes. The study included 44 coal miners (mean age 44) and 65 individuals not exposed to coal (mean age 38). Blood samples were collected between March 2009 and January 2011. DNA damage was evaluated by Comet Assay (Damage Index - DI and Damage Frequency - FD) and genotyping of metabolizing (GSTM1, GSTT1 and CYP1A1) and repair (OGG1, XRCC1) polymorphisms were performed by PCR-RFLP method. Coal miner cells presented significantly higher DI and DF (18 \pm 9.72 and $14 \pm 6.90$, respectively) compared with non-exposed individuals $(5 \pm 5.81$ and $2 \pm 2.08$, respectively; both $\mathrm{p}<0.001$ ). The results considering susceptibility genotypes showed no significant differences. The Micronucleus Test was used on epithelial buccal cells (EBCyt), to detect micronuclei, chromosomal instability, cell death and regenerative potential. The study included 28 coal miners (mean age $41.93 \pm 13.55$ ) from Candiota (where a coal mine and a power plant are located) and 54 individuals not exposed to coal (mean age $44.46 \pm 7.12$ years). The samples were collected from March 2009 to January 2011. The EBCyt indicated significant increase in nuclear bud frequency in the exposed group $(22.48 \pm 0.88)$ compared to the non-exposed group $(0.57 \pm 0.88 ; \mathrm{p}<$ 0.0001 ). A difference in cytokinetic defects (binucleated cells) was observed between the exposed $(25.21 \pm 12.04)$ and non-exposed group $(7.43 \pm 5.32 ; \mathrm{p}<0.0001)$. An increase in cell death frequency (condensed chromatin, karyorrhetic, karyolytic and pyknotic cells) was observed in the exposed group in relation to the non-exposed group $(\mathrm{p}=0.0001)$. Proliferative potential (basal cell frequency) was reduced in the exposed group $(1945 \pm 20.32)$ in comparison to the non-exposed group $(1841 \pm 62.09$ $\mathrm{p}=0.0001$ ). Our results indicate cytotoxicity and dead cells in cells of coal miners, which can be associated with lack or 
non-use of protection equipment. In conclusion, our results point towards a genotoxic effect of coal exposure and agree with previous data on coal and derivatives, mainly PAHs.

\section{Conclusions}

Our studies have shown genotoxic effects in the industries we analyzed (exposure to pesticides in vineyard and tobacco farmers, exposure to solvents and/or dust in footwear and tannery workers, and to coal in open-cast mining workers). We were able to associate it with specific genetic susceptibility for each type of exposure and, also with the non-use or inappropriate use of the personal protection equipment and diet adequacy. These results show how important continuous education is for exposed workers in order to minimize effects of occupational exposure and the risk of disease associated with the work.

\section{Acknowledgments}

Financial support was provided by Conselho Nacional de Desenvolvimento Científico e Tecnológico (CNPq) and Fundação de Amparo à Pesquisa do Estado do Rio Grande do Sul (FAPERGS).

\section{References}

Angerer J, Ewers U and Wilhelm M (2007) Human biomonitoring: State of the art. Int $\mathrm{J}$ Hyg Environ Health 210:201-228.

Arbuckle TE, Lin Z and Mery LS (2001) An exploratory analysis of the effect of pesticide exposure on the risk of spontaneous abortion in an Ontario farm population. Environ Health Perspect 109:851-857.

Au WW, Sierra-Torres CH, Cajas-Salazar N, Shipp BK and Legator MS (1999) Cytogenetic effects from exposure to mixed pesticides and the influence from genetic susceptibility. Environ Health Perspect 107:501-505.

$\mathrm{Au}$ WW, Navasumrit P and Ruchirawat M (2004) Use of biomarkers to characterize functions of polymorphic DNA repair genotypes. Int J Hyg Environ Health 207:301-313.

Bagchi D, Stohs SJ, Downs BW, Bagchi M and Preuss HG (2002) Cytotoxicity and oxidative mechanisms of different forms of chromium. Toxicology 180:5-22.

Blair A, Grauman DJ, Lubin JH and Fraumeni Jr JF (1983) Lung cancer and other causes of death among licensed pesticide applicators. J Natl Cancer Inst 71:31-37.

Bolognesi C (2003) Genotoxicity of pesticides: A review of human biomonitoring studies. Mutat Res 543:251-272.

Bonassi S and Au WW (2002) Biomarkers in molecular epidemiology studies for health risk prediction. Mutat Res 511:7386.

Bonassi S, Ugolini D, Kirsch-Volders M, Stromberg U, Vermeulen R and Tucker JD (2005) Human population studies with cytogenetic biomarkers: Review of the literature and future prospectives. Environ Mol Mutagen 45:258-270.

Cebulska-Wasilewska A (2003) Response to challenging dose of $\mathrm{X}$-rays as a predictive assay for molecular epidemiology. Mutat Res 544:289-297. da Silva J, Freitas TRO, Marinho JR, Speit G and Erdtmann B (2000) An Alkaline single-cell gel electrophoresis (comet) assay for environmental biomonitoring with native rodents. Genetics and Molecular Biology 23:9868-9874.

da Silva J, Moraes CR, Heuser VD, Andrade VM, Silva FR, Kvitko K, Emmel V, Rohr P, Bordin DL, Andreazza AC, et al. (2008) Evaluation of genetic damage in a Brazilian population occupationally exposed to pesticides and its correlation with polymorphisms in metabolizing genes. Mutagenesis 23:415-422.

Donbak L, Rencuzogullari E, Yavuz A and Topaktas M (2005) The genotoxic risk of underground coal miners from Turkey. Mutat Res 588:82-87.

Dougherty J (1998) Employee health monitoring data bases and their role in defining the safety of chemical products. Int Arch Occup Environ Health 71 Suppl:S101-103.

Dusinska M and Collins AR (2008) The comet assay in human biomonitoring: Gene-environment interactions. Mutagenesis 23:191-205.

Fairbairn DW, Olive PL and O'Neill KL (1995) The comet assay: A comprehensive review. Mutat Res 339:37-59.

Falck GC, Hirvonen A, Scarpato R, Saarikoski ST, Migliore L and Norppa H (1999) Micronuclei in blood lymphocytes and genetic polymorphism for GSTM1, GSTT1 and NAT2 in pesticide-exposed greenhouse workers. Mutat Res 441:225237.

Fenech M (2011) Micronuclei and their association with sperm abnormalities, infertility, pregnancy loss, pre-eclampsia and intra-uterine growth restriction in humans. Mutagenesis 26:63-67.

Flowers L, Broder MW, Forsyth C and United States Environmental Protection Agency (2003) Toxicological review of acetone (CAS No. 67-64-1) in support of summary information on the integrated risk information system (IRIS). US Environmental Protection Agency, Washington, DC.

Gauthier E, Fortier I, Courchesne F, Pepin P, Mortimer J and Gauvreau D (2001) Environmental pesticide exposure as a risk factor for Alzheimer's disease: A case-control study. Environ Res 86:37-45.

Goode EL, Ulrich CM and Potter JD (2002) Polymorphisms in DNA repair genes and associations with cancer risk. Cancer Epidemiol Biomarkers Prev 11:1513-1530.

Granella M and Clonfero E (1992) Sensitivity of different bacterial assays in detecting mutagens in urine of humans exposed to polycyclic aromatic hydrocarbons. Mutat Res 268:131-137.

Grevatt PC and United States Environmental Protection Agency (1998) Toxicological review of trivalent chromium (CAS No. 16065-83-1) in support of summary information on the integrated risk information system (IRIS). US Environmental Protection Agency, Washington, DC.

Grover P, Danadevi K, Mahboob M, Rozati R, Banu BS and Rahman MF (2003) Evaluation of genetic damage in workers employed in pesticide production utilizing the Comet assay. Mutagenesis 18:201-205.

Gu ZW, Whong WZ, Wallace WE and Ong TM (1992) Induction of micronuclei in BALB/c-3T3 cells by selected chemicals and complex mixtures. Mutat Res 279:217-222.

Hao B, Wang H, Zhou K, Li Y, Chen X, Zhou G, Zhu Y, Miao X, Tan W, Wei Q, et al. (2004) Identification of genetic variants in base excision repair pathway and their associations 
with risk of esophageal squamous cell carcinoma. Cancer Res 64:4378-4384.

Hardell L and Eriksson M (1999) A case-control study of nonHodgkin lymphoma and exposure to pesticides. Cancer 85:1353-1360.

Heuser VD, de Andrade VM, da Silva J and Erdtmann B (2005) Comparison of genetic damage in Brazilian footwearworkers exposed to solvent-based or water-based adhesive. Mutat Res 583:85-94.

Heuser VD, Erdtmann B, Kvitko K, Rohr P and da Silva J (2007) Evaluation of genetic damage in Brazilian footwearworkers: Biomarkers of exposure, effect, and susceptibility. Toxicology 232:235-247.

Ji BT, Silverman DT, Stewart PA, Blair A, Swanson GM, Baris D, Greenberg RS, Hayes RB, Brown LM, Lillemoe KD, et al. (2001) Occupational exposure to pesticides and pancreatic cancer. Am J Ind Med 39:92-99.

Keshava N and Ong TM (1999) Occupational exposure to genotoxic agents. Mutat Res 437:175-194.

Khuder SA and Mutgi AB (1997) Meta-analyses of multiple myeloma and farming. Am J Ind Med 32:510-516.

Kogevinas M, Kauppinen T, Winkelmann R, Becher H, Bertazzi PA, Bueno-de-Mesquita HB, Coggon D, Green L, Johnson E, Littorin M, et al. (1995) Soft tissue sarcoma and nonHodgkin's lymphoma in workers exposed to phenoxy herbicides, chlorophenols, and dioxins: Two nested case-control studies. Epidemiology 6:396-402.

Leon-Mejia G, Espitia-Perez L, Hoyos-Giraldo LS, Da Silva J, Hartmann A, Henriques JA and Quintana M (2011) Assessment of DNA damage in coal open-cast mining workers using the cytokinesis-blocked micronucleus test and the comet assay. Sci Total Environ 409:686-691.

Leonard A, Deknudt G, Leonard ED and Decat G (1984) Chromosome aberrations in employees from fossil-fueled and nuclear-power plants. Mutat Res 138:205-212.

Life Systems Inc, United States Agency for Toxic Substances and Disease Registry and United States Environmental Protection Agency (1994) Toxicological profile for acetone. Agency for Toxic Substances and Disease Registry, U.S. Public Health Service, Atlanta.

Life Systems Inc, United States Agency for Toxic Substances and Disease Registry and United States Environmental Protection Agency (1999a) Toxicological Profile for Formaldehyde. Agency for Toxic Substances and Disease Registry, US Public Health Service, Atlanta, xvii +42 pp.

Life Systems Inc, United States Agency for Toxic Substances and Disease Registry and United States Environmental Protection Agency (1999b) Toxicological Profile for n-hexane. Agency for Toxic Substances and Disease Registry. US Public Health Service, Atlanta, xix + 230 pp.

Life Systems Inc, United States Agency for Toxic Substances and Disease Registry and United States Environmental Protection Agency (2000) Toxicological Profile for Tolueno. US Public Health Service, Atlanta, xix +312 pp.

Life Systems Inc, United States Agency for Toxic Substances and Disease Registry and United States Environmental Protection Agency (2008) Draft Toxicological Profile for Chromium. Agency for Toxic Substances and Disease Registry. U.S Public Health Service, Atlanta, xx +520 pp.

Life Systems Inc, United States Agency for Toxic Substances and Disease Registry and United States Environmental Protec- tion Agency (2010) Addendum to the Toxicological Profile for 2-Butanone. Agency for Toxic Substances and Disease Registry, US Public Health Service, Atlanta, iv + 13 pp.

McBride JS, Altman DG, Klein M and White W (1998) Green tobacco sickness. Tob Control 7:294-298.

Medeiros MG, Rodrigues AS, Batoreu MC, Laires A, Rueff J and Zhitkovich A (2003) Elevated levels of DNA-protein crosslinks and micronuclei in peripheral lymphocytes of tannery workers exposed to trivalent chromium. Mutagenesis 18:19-24.

Moller P, Knudsen LE, Loft S and Wallin H (2000) The comet assay as a rapid test in biomonitoring occupational exposure to DNA-damaging agents and effect of confounding factors. Cancer Epidemiol Biomarkers Prev 9:1005-1015.

Muniz JF, McCauley L, Scherer J, Lasarev M, Koshy M, Kow YW, Nazar-Stewart V and Kisby GE (2008) Biomarkers of oxidative stress and DNA damage in agricultural workers: A pilot study. Toxicol Appl Pharmacol 227:97-107.

Pastor S, Creus A, Parron T, Cebulska-Wasilewska A, Siffel C, Piperakis S and Marcos R (2003) Biomonitoring of four European populations occupationally exposed to pesticides: Use of micronuclei as biomarkers. Mutagenesis 18:249-258.

Rajaram R, Nair BU and Ramasami T (1995) Chromium(III) induced abnormalities in human lymphocyte cell proliferation: Evidence for apoptosis. Biochem Biophys Res Commun 210:434-440.

Rohr P, da Silva J, Erdtman B, Saffi J, Guecheva TN, Henriques, JAP and Kvitko K (2011) BER gene polymorphisms (OGG! SerCYS and XRCC1 Arg 194Trp) and modulation of DNA damage due to pesticides exposure. Environ Mol Mutagen 52:20-27.

Shaham J, Kaufman Z, Gurvich R and Levi Z (2001) Frequency of sister-chromatid exchange among greenhouse farmers exposed to pesticides. Mutat Res 491:71-80.

Shukla Y and Arora A (2001) Transplacental carcinogenic potential of the carbamate fungicide mancozeb. J Environ Pathol Toxicol Oncol 20:127-131.

Simpson JR and Gibson RS (1992) Hair, serum, and urine chromium concentrations in former employees of the leather tanning industry. Biol Trace Elem Res 32:155-159.

Siwinska E, Mielzynska D and Kapka L (2004) Association between urinary 1-hydroxypyrene and genotoxic effects in coke oven workers. Occup Environ Med 61:e10.

Sram RJ, Hola N, Kotesovec F and Novakova A (1985) Cytogenetic analysis of peripheral blood lymphocytes in glass workers occupationally exposed to mineral oils. Mutat Res 144:277-280.

Stierum RH, Hageman GJ, Welle IJ, Albering HJ, Schreurs JG and Kleinjans JC (1993) Evaluation of exposure reducing measures on parameters of genetic risk in a population occupationally exposed to coal fly ash. Mutat Res 319:245-255.

Stupar J, Vrtovec M, Kocijancic A and Gantar A (1999) Chromium status of tannery workers in relation to metabolic disorders. J Appl Toxicol 19:437-446.

Sturgis EM, Castillo EJ, Li L, Zheng R, Eicher SA, Clayman GL, Strom SS, Spitz MR and Wei Q (1999) Polymorphisms of DNA repair gene XRCC1 in squamous cell carcinoma of the head and neck. Carcinogenesis 20:2125-2129.

United Nations Environment Programme, International Labour Organisation, World Health Organization and International Program on Chemical Safety (2001) Biomarkers in risk as- 
sessment: Validity and validation. World Health Organization, Geneva, xiv +238 pp.

United States Environmental Protection Agency (2003) Toxicological review of methyl ethyl ketone (CAS No. 78-93-3) in support of summary information on the Integrated Risk Information System (IRIS). US Environmental Protection Agency, Washington, DC, 152 pp.

Uuksulainen SO, Heikkila PR, Olkinuora PS and Kiilunen M (2002) Self-reported occupational health hazards and measured exposures to airborne impurities and noise in shoe repair work. Int J Occup Environ Health 8:320-327.

Verschaeve L and Gilles J (1995) Single cell gel electrophoresis assay in the earthworm for the detection of genotoxic compounds in soils. Bull Environ Contam Toxicol 54:112-119.

Ward EM, Schulte PA, Bayard S, Blair A, Brandt-Rauf P, Butler MA, Dankovic D, Hubbs AF, Jones C, Karstadt M, et al. (2003) Priorities for development of research methods in occupational cancer. Environ Health Perspect 111:1-12.

Weselak M, Arbuckle TE, Wigle DT, Walker MC and Krewski D (2008) Pre- and post-conception pesticide exposure and the risk of birth defects in an Ontario farm population. Reprod Toxicol 25:472-480.
Wilkinson JT and Clapper ML (1997) Detoxication enzymes and chemoprevention. Proc Soc Exp Biol Med 216:192-200.

Zeljezic D and Garaj-Vrhovac V (2001) Chromosomal aberration and single cell gel electrophoresis (Comet) assay in the longitudinal risk assessment of occupational exposure to pesticides. Mutagenesis 16:359-363.

Zeljezic D and Garaj-Vrhovac V (2002) Sister chromatid exchange and proliferative rate index in the longitudinal risk assessment of occupational exposure to pesticides. Chemosphere 46:295-303.

Zheng T, Zahm SH, Cantor KP, Weisenburger DD, Zhang Y and Blair A (2001) Agricultural exposure to carbamate pesticides and risk of non-Hodgkin lymphoma. J Occup Environ Med 43:641-649.

\section{Internet Resources}

AFUBRA (2011) Associação dos Fumicultores do Brasil, http://www.afubra.com.br (September, 2011).

License information: This is an open-access article distributed under the terms of the Creative Commons Attribution License, which permits unrestricted use, distribution, and reproduction in any medium, provided the original work is properly cited. 